\title{
The Role of Populism in the Development of Illiberal Democracy in Hungary
}

\author{
Maria Bordas \\ University of Public Service Ludovika
}

In the late 80's Hungary was a leading post-Communist country which successfully implemented certain reforms of economic governance, and in the 90's introduced liberal democracy and market-oriented economy. However, after two decades, in 2010, based upon the gained 2/3 majority parliamentary seats in Hungarian parliament, Viktor Orbán, the new prime minister, started to build up an autocracy in Hungary. He named his governing system "illiberal democracy."

The Orbán system of governance is obviously autocratic but is still alike democracy having mocked democratic institutions. This Janus-faced nature of the Orbán regime will be examined by the paper. Viktor Orbán successfully using nationalist-populist communication, too.

This paper tries to shed light on the reasons of development of illiberal democracy in the European Union by examining the case in Hungary. It highlights the real beneficiaries and losers of the Orbán's illiberal democracy. The price of partially giving up certain principles of liberal democracy, such as checks and balances, political pluralism, economic equality of market constituents, or the rule of law, will be explored.

Keywords: illiberal democracy, post-communist countries, transition, modernization, economic governance, public administration reform

\section{INTRODUCTION}

Traditionally, prime minister Orbán makes a speech at the opening of the Bálványos Open University and Student Camp in the picturesque Romanian town of Tusványos. ${ }^{1}$ This event has become the mostattended event for right-wing Hungarian intelligentsia loyal to FIDESZ. In 2014, the prime minister Orbán's speech generated the biggest waves internationally as Mr. Orbán set out a vision for an "illiberal state" that became a template for nationalist-populists everywhere.

In 1989, Fukuyama in his essay ""The End of History?" gives his vision about the dominance of Western liberal democracy globally as the final form of human government. ${ }^{2}$ Unfortunately, it did not prove to be real. According to the Democracy Index 2020 produced by the Economist Intelligence Unit, political authoritarianism is spreading and democracy in retreat: ${ }^{3}$ the number of authoritarian regimes increased to 54 from 52 of last year. ${ }^{4}$ Populism has been spread during the last decade and aims to establish autocratic political and government systems, even in the European Union and the United States, due to the growing number of poor and the sliding down middle class. Autocratic leaders can successfully use the phenomena for their goal to eliminate illiberal democracy, at the same time to make their political power nonremovable. 
Herman Goering said: Naturally the common people don't want war. . . but after all it is the leaders of a country who determine policy, and it is always a simple matter to drag the people along. ${ }^{5}$ In accordance with some academics, there are commons between Orbán government communications and right-wing populism. ${ }^{6}$ We could evidently find this way of propaganda in the Orbán's anti-EU, anti-liberal and antiimmigrants' speeches or verbal attacks against American-Hungarian liberal billionaire, George Soros.

Traditionally, prime minister Orbán makes a speech at the opening of the Bálványos Open University and Student Camp in the picturesque Romanian town of Tusványos. ${ }^{7}$ This event has become the mostattended event for right-wing Hungarian intelligentsia loyal to FIDESZ. In 2014, the prime minister Orbán's speech generated the biggest waves internationally as Mr. Orbán set out a vision for an "illiberal state" that became a template for nationalist-populists everywhere.

Prime minister Orbán, the populist leader is turning towards an alternative political and social model in which the cultivation of "traditional values" and distinct national identities has paramount ideological importance. The Orbán government under the logo of so-called "building national capitalist class" is using the government-system for corruption, which means that EU founds are provided for "paraselene", i.e., business firms of his loyalist supporters.

Development of illiberal democracy in the European Union occurred in Hungary since 2010 for the first time, also, it was the most spectacular here. In this paper we shall analyse all segments of this phenomena.

\section{OVERDUE MODERNIZATION IN THE REGIONS OF EAST OF THE ELBE}

In the regions east of the Elbe, there was no tradition of liberal democracy among the institutions. Bourgeois revolutions erupted with considerable delays, because the capitalist socio-economic conditions developed later and in a manner contradictory to the framework of feudalism. In these countries, modernisation began with the reform initiatives of enlightened absolutist rulers, which led to the development of the institutions of capitalist economies, but without a strong civilian base in the background, which would have been dedicated to the creation of a liberal democratic state.

In the mid-19th century, the civil revolutions unfolding in these regions were unable to achieve spectacular results in terms of the institutions' establishment of the rule of law, constitutionality, popular sovereignty, and political freedoms. The first bourgeois democratic states formed in the first half of the 20th century in Central-East Europe were no longer able to take shape because of the spread of fascism, so during their short-term period of operation they were unable to create the traditions of liberal democracy. After World War II, the process of modernisation of states under the influence of the Soviet Union in

It is happened because in these countries the Soviet state and economic governance model had been violently introduced. The Soviet state model resulted a foreign body in the Central and Eastern European countries, where Western-type liberal democracies had been introduced at the beginning of the 20th century. The Soviet Communist model, which, thanks to the Bolshevik party's sense of mission, wanted to establish a higher order of social and economic systems in comparison with capitalism, but because of lacking democratic traditions remained a system based upon violence and totalitarian ideology, later just focused on exclusively maintaining the power of the Bolshevik Party.

The so-called "War Communism", and later its reformed version, the conceptual system of economy management based upon planning directives, could not increase economic efficiency and it became increasingly apparent that it was significantly lagging the developed Western market economies. The promise of the Communist state that the sacrifices the population endured would only be temporary was not fulfilled and living conditions deteriorated constantly. The Soviet state began to erode itself. This erosion was accelerated by protests, uprisings and revolutions taking place in Central and Eastern European regions.

After the collapse of the Soviet political system in post-Communist states, the processes of modernisation took place in a controversial way. The most important issue for the Central-East European states was that the states had just been liberated from the Communist shackles now had to find out which kind of values should be followed. There was no old tradition of public administration working in a 
democratic state system in these countries, because the democracies that had preceded the fascist dictatorships before World War II were short-lived and too fragile. The institutions of Western-type liberal democracy could not have taken root and become a tradition.

In post-Communist countries in Central-East Europe, from the transition period, i.e., from the 1990s, the question of modernization emerged differently from the Western countries. Considering that there was no tradition of democratic state structure and market economy in these countries, the establishment of these institutions was not free of conflicts. It emerged as a dilemma which one should be introduced from among the governmental systems and economic governance models already used in the developed Western states, which also represented several trends under the umbrella of liberal democracy itself.

In contrast to developed Western states having administrative systems with centuries of a rule of law culture, the post-Communist states did not have an answer as to whether there was room for the American theory of efficiency and practice. Many wondered if it should be treated as a fundamentally foreign body. Others emphasised the fact that some elements of efficiency can be successfully applied in the Weberian administrative model, based however on old-fashioned bureaucratic traditions.

Instead of the Communist state, the institutions of the democratic state, which ensured the separation of the branches of state power, the system of checks and balances, the constitutionality, the rule of law, the exercise of the controlling bodies' functions and the rights of local self-government, were the first to be created. The bureaucratic planned economic system had to be replaced by a market economy model operated by institutions of Western-style economic governance based upon economic constitutionality, social market economy, market competition and business freedom.

The development of the Hungarian post-Communist state model is a good example of searching for the way out, experimenting with the creation of several models leading to extreme administrative systems during the transition period over the past 28 years. Hungary was the first state in the European Union, where the so called "illiberal democracy" (Zakaria F., 1997. 3) developed since the 2010s. This government system evidently violates certain values of the treaties of the European Union, despite, seems to have stabilized itself during the last decade. Even more, it serves as an example for some other countries in the region of Central East European countries post-communist countries.

\section{PROBLEMS OF MODERNIZATION IN HUNGARY IN EARLY 20TH-CENTURY}

\section{Autocratic Traditions of the Horthy System}

The transition period since 2010 in Hungary was determined by the traditions characterizing the state organization of the Horthy's system. In the ideology of the government of 2010, is in many respects like the government system established in 1919, which was primarily governed by autocratic features. The dominant, multi-faction conservative political gathering parties, representing primarily the big holder aristocracy, the middle-class nobility, the big and middle capitalist class, and, but in lesser extent, the middle-class and the peasant holders, emphasized parliamentary democracy but rejected the liberal democracy that regarded as the "rule of the raw masses". Compared to the conservative governmental parties, one of the poles was the socialist, liberal, and agricultural parties, with little support, and the second pole of the far-right party, which gained more and more influence in parliament in the 1930s.

The law on the election was amended at that time by government decree which promoted the supporters of the conservative parties in the way of reducing the right of $80 \%$ of the population to vote and replacing the secret voting with open one in the rural areas.

The governor position of Miklós Horthy established in 1920, had a large power but did not expand beyond the usual roles of a strong presidential system. According to the law, the government was controlled by the Parliament, but regarding the political interconnection of the two powers, that is to the massive parliamentary majority, the Parliament did not exercise substantive control over the government. In addition, the weight of regulatory governance increased in times of crisis, especially during the war. Local governance was controlled by the institutes appointed by the county councils. The municipal elections did not follow the principle of universal and equal suffrage, as the social groups having privileges, e.g., the wealthy layers, the professional roles, or the religious denominations were to be the major part of the 
eligible members of county councils. (Romsics, I. 1997. 1.) With regards political and freedom rights, it can be stated that freedom of press, in particular, had been restricted by censorship, by banning newspapers and press reports, or by suing the journalists. The restriction of freedom of association and assembly was mainly hit by the members of the Communist and the far-right political parties who were usually imprisoned for their political activities. The religious and racial discrimination of the Jews had been gradually extended since 1920.

However, the Horthy system retained the character of parliamentary democracy until the beginning of the $1930 \mathrm{~s}$, but not as a liberal democracy. Due to the governmental system with autocratic features, where general and equal suffrage did not prevail, political and freedom rights were limited, and local government entirely lacked the principle of municipal autonomy. However, the governments formed since 1932 became more and more fascist, and in 1944, after the Arrow Cross Party (Hungarian Nazi Party) had taken over the political power, the country became an open dictatorship.

\section{The Reform Attempts of the Hungarian Communist Party After the Revolution of 1956}

In Hungary, from 1947, in the era marked by the name of Mátyás Rákosi, a Stalinist Soviet model emerged, characterised by personal culture and the unbridled terror of the Communist Party. By the middle of the 1950s, these elements mentioned above undermined the stability of the political power of the Rákosi regime. The internal opposition of the Communist Party was removed by means of conceptual lawsuits, the old power elite was executed, deported, or expelled.

The Soviet-style system of state planning, which emphasised forced industrialisation and the development of the military industry, could not set the economy on the track of permanent development. During nearly ten years after the Communist party came to power, the population was increasingly suffering the depths of misery.

After the collapse of the 1956 Revolution, the question of the reform of economic governance could not have arisen in the atmosphere of repression, and thus was only reconsidered in 1968. The economic reform of 1968 aimed at increasing the self-sufficiency of state-owned enterprises by conceding that they were only interested in better economic performance in this way. So, their operation becomes more efficiently if they can make autonomous economic decisions and can deal with the profits they produce. This new system of economic governance was given the indicator of "indirect" as a tag, representing a more liberal system of management by using economic regulators instead of planning directives of the Soviet model.

The indirect system of economic governance, the central administration was also transformed: the number of ministries decreased significantly, and their tasks were restructured. The central functional state administration bodies, such the Ministry of Finance, the Planning Office, the Pricing and Payroll Office and the Ministry of Labour, were established. These organisations guided the economy, with the tools of economic regulators, in accordance with their responsibilities. The central sectoral public administration bodies supervised certain sectors of the economy, for example agriculture, industry, and commerce, primarily through the development of sectoral policies and partly by state-owned enterprises.

In 1984, a new economic governance reform was introduced. The reason for this attempt at reform was that the Communist party-state wanted to develop the reform of 1968, as it had only declared the independence of state-owned enterprises, however, had not given them any real guarantees. The economic organisational and legal reform of 1984 gave state-owned enterprises greater economic autonomy, and supported organisational and legal guarantees, as well. Self-governing bodies of state-owned enterprises were set up, consisting of workers' representatives. They exercised real owners' rights: appointing and dismissing directors and deciding on all the economic issues of the state-owned enterprise. Public authorities managing state-owned enterprises, could only then have lawful control over state-owned enterprises. In other words, they could only supervise their lawful functioning, but no longer had the right to give direct instructions to companies in economic affairs.

The 1984 economic organisational and legal reform detached the state-owned enterprises from governing public authorities and entrusted the exercise of ownership rights to self-governing bodies. (Lörincz L. 1981.187-226.) However, the state-owned enterprises were the entrepreneurial assets of the 
state, the operation of which would have required ownership decisions that self-governing bodies managing the state-owned enterprise were not able to undertake. They did not behave as real owners, because their members, being at the same time the employees, did not have interests of ownership, and could not operate as real, true business ventures.

These economic governance reforms failed to come up to the expectations. It was because it had been proved that although the Hungarian experiments at reform were a significant step forward compared with the direct planning approach, the efforts at efficiency could not be implemented consistently in a centralised, bureaucratic economic governance system based on the exclusivity of state ownership, and in which market mechanisms could prevail only in a limited way. (Kornai J. 1991, 1026-1028)

The uniqueness of the Hungarian Communist economic governance model lies in the fact that the exclusivity of the state's economic control role had been broken up by the end of the 1980s. In the economy outside the public sector, private forms of entrepreneurship emerged, though these did not become dominant in the entire economy. As a result, a small business market emerged on the periphery of the economy, called the "second economy". (Csillag I. - Lengyel L. 1985. 97-199.) These reform efforts triggered a process in which the transformation of the regime in the economy was not executed in a revolutionary fashion, but pragmatically and "gradually evolved in hidden way - in the womb of the "Kádár system". (Sárközi T. 2009. 34.)

The economic governance reforms of the Kádár system did not solely intend to increase economic efficiency, but also economic growth, which served as a basis to implement a specific social policy that could provide the population with a higher standard of living.

From the middle of the 1970s, certain forms of small business of the individuals were approved, and later it was also possible to operate various small businesses of the state-employees even within the stateowned enterprises. With these elements, the Kádár system provided to the population with additional income and enabled higher consumption. In the European Communist states, this was quite exceptional. Central labour management together with central price and wage regulation made it possible for everyone to have job and access to basic consumer goods and public services. However, this improvement in living standards was not just because of the economy's better performance, but also thanks to the foreign loans arranged by the Kádár government.

Hungary was an exception in the Soviet bloc because the Communist Party could succeed by improving the welfare of the population. Under an implicit social agreement, in exchange for prosperity, the population did not initiate movements of dissatisfaction after the 1956 revolution. Most of the population in Hungary accepted the Communist leadership in the late Kádár era, too, for it made political and cultural life more liberal. As a result, the significance of the reprisals after the repression of the 1956 revolution was diminished. With the reforms of economic governance, the Kádár system created so-called "market socialism", commonly known as "goulash Communism", which could, through the relative liberalisation of the economy, achieve the raising of the standard of living, wealth, and consumption of the population. Hungary was therefore referred to as the "most idyllic barracks" in the Communist community.

The welfare policy created by the Kádár system introduced a paternalistic tradition in Hungary, which later survived. During the period of transition, since 1990's, and subsequently, the population continued to expect state care, especially those who were not competitive in the labour market in the framework of real market economy conditions. As a result of this trend, an increasing proportion of the population left the labour market and became dependent on state social support.

The Kádár regime's economic and social policy resulted in a large part of the population's deeply rooted tradition of not articulating its interests in a pluralistic political system, but also an involved agreement with the political power, trusting its ability to act in the nation's interest. Since in the history of Hungary the bourgeois democratic state did not develop even until the mid-20th century, the liberal democracy did not have any traditions. These circumstances greatly contributed to the establishment of the model of illiberal democracy in 2010. 


\section{POST-COMMUNIST HUNGARIAN PUBLIC ADMINISTRATION DURING THE TRANSITIONAL PERIOD}

\section{The Peculiarities of the Political System}

The modernisation process of the Hungarian public administration has not shown steady progress in the last past quarter of a century, one reason for which could be found in the peculiarities of the Hungarian political system. During the Communism, the state organisation was dominated by the Communist Party, and since it organised the civil organisations from the top, the Communist state was able to maintain strict control over society, and consequently could shape it to its own image. Civilian self-governance and solidarity therefore had no tradition, so there was no demand from the public to limit or control public authorities. In this dictatorial state, civic consciousness did not exist, because individuals were characterised as having subordinate attitudes and the population was not devoted to political and freedom rights.

The institutions of liberal democracy were established in the early 1990s in the state organisation, on the ground that the negotiations of the so-called "round table opposition political groups" (including the reform wing of the Hungarian Communist Party), and the modification of the Communist constitution of 1949.

The socialist and liberal parties in Hungary considered the American system of public administration based on the principles of liberalism to be ideal by emphasizing the rhetoric of American neoliberalism: market mechanisms, competition, minimum state involvement, more self-care and the importance of political rights and rights to freedom. The other extreme case is represented by the right-wing state organisation model that emerged in 2010 , in which the role of one political party is dominant. This state system is characterised by centralisation, limitation of checks and balances, and massive state intervention. This ideology emphasizes national sovereignty and national economic interest against the globalisation tendencies.

The other drawback of the process of Hungarian modernisation was the ultimate opposition of the two political sides. To achieve the most important reforms or the amendment of the Constitution itself, the Constitution required that an act be adopted by a two-thirds majority in the parliament, but there was never a consensus between the current government parties and the opposition. The socialist-liberal political side, on one hand, held completely opposing ideas about the institutions of a market economy, state intervention, state ownership, privatisation, or the level of welfare institutions from those of the right-wing side, on the other hand.

In the political struggle between the two opposing sides, all other aspects seemed to be subordinated to the acquisition and retention of political power. Party financing and grants to business firms close to the political parties from the state financial resources, placed government above all other goals. It was because this provided them with the success of election campaigns and the creation of their own media empire. Building the "spoil system" too solidly and thus including political loyalty in the appointment of administrative positions, also served this political aim. With this, the principle of expert governance became underdeveloped, and the public administration expert apparatus became subject to daily political interests.

Due to the inability of the two political sides to reach consensus, it has become impossible to create and implement long-term economic and social policy concepts. Government programmes were therefore necessarily short-term, for a term of government or an even shorter time. After the elections, the governing parties usually expunged the results of the former government and pursued a completely different concept that made reform processes chaotic. The public administration consequently became over-politicised and government decisions were increasingly determined by party political considerations, causing serious disruption to the exercise of public administration, as there was no political mechanism that would have been able to formulate public interests.

Leftist and liberal economic governance during the 2000-s had been less and less capable of addressing the economic problems, which later worsened the effects of the global economic crisis in 2007. These governments increasingly became unpopular due to the advice of the international financial institutions, which suggested introducing new austerity measures. The population regarded it as a symbol of weak and powerless governance vulnerable to global economic processes. The values of the neoliberal economic 
philosophy did not have real public support in Hungary. Rather, instead, they believed that a strong and caring state was able to execute the requirements of efficiency. All this was still borne out by the evergrowing corruption scandals that referred to the involvement of leading government officials and politicians. As a result, the left-wing and liberal ruling parties lost their landslide popularity, which resulted in the right-wing party's winning in the parliamentary elections of 2010, and then the overwhelming winning of the municipal elections that followed, gaining two-thirds majority in parliament and then in vast majority of local governments.

\section{The Political Conception of the Steps to Build Illiberal Democracy in Hungary}

The ideology of "majority democracy" emerged in 2010, argued that political will was too fragmented in the former Hungarian political system because of the constant value debates and the social divide, and therefore the country had become unmanageable. The winning right-wing party also highlighted that the lack of modernisation was evident in the fact that the left-wing party, as the successor to the Communist party, had transformed its former political power into economic power, had exclusively ruled public administration for two decades, and had not used it for the public good. It had provided the country with the effects of globalisation, and its economic policy was individualistic and produced excessive privatisation. At the expense of the middle class, merely for the purpose of gaining votes, it supported the downsized groups who were living on state subsidies and were thus heavily dependent on the state. The economic basis of its political power was the granting of its own "paraselene" to the material benefits through state corruption.

Therefore, according to the ideology of majority democracy, there was a need for a political power, the

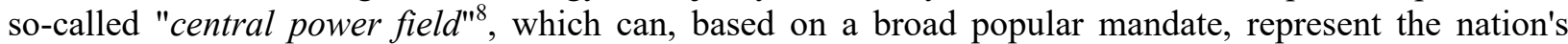
interest in the long term, and can fulfil its national economic policy. The legitimacy of the new political power is - according to the argument - that the most voters support the national economic policy, so it must be regarded as a matter of public interest.

The majority democracy model is based on the principle of popular representation, according to which the demands of a political party with an absolute majority in the parliament should be considered legitimate for a government decision to be implemented quickly and easily in the public administration. It has implemented the following steps: restricted the checks and balances in the state system, the powers of the controlling bodies; centralised the public administration; extended the "spoil system" to the election of politically loyal public dignitaries and major public officials; controlled trade unions in order to facilitate the implementation of the reforms deemed necessary; as well as increased state ownership and the scope of state monopolies in order to overcome barriers to the government's attempts at economic intervention.

Majority democracy is hoped by many to become a more efficient state-organisation model in Hungarian political conditions, but it is the price of partially giving up certain principles of liberal democracy, such as checks and balances, political pluralism, economic equality of market constituents, or the rule of law.

This government established in 2010, is also referred to as "illiberal democracy", facing with developed western states' liberal democracy already having centuries of democratic traditions. In Hungary, this means that a ruling party gaining two-thirds majority in parliament in 2010 (and then in 2014 and 2018), with a broad popular mandate as its own legitimacy, has created a new constitution, also, transformed the public law system. They did all this with the unhidden aim of minimizing the chances of government being replaced by the means of parliamentary democracy.

The most important step in building "illiberal democracy" was the creation of a new electoral law adapted by the ruling party to the political party structure emerged in 2010, so that the government can assume its long-term survival. The non-proportional electoral system thus created allows a party to form a government that did not achieve at least half of the votes in the elections, only the relative majority. The seats in Parliament are not proportionate to the number of votes obtained. After the 2014 and 2018 elections, the ruling party, despite gaining less than half its votes, again received parliamentary seats leading to twothirds majority. It is a fact that "majority democracy" has been based on the votes of $30 \%$ of eligible electors and slightly less than $50 \%$ of actual electors. 
Electors voting for the ruling party are quite heterogeneous in terms of why they support the government's economic and social policies. According to some surveys, about one fifth of the population feels that they have been the winner of government policy since 2010. Half of the supporters of the government comes from the middle class, whose income has been significantly increased by the government. This social layer, which includes most of the upper middle class, accepts inequalities of opportunity and large social differences based on the conservative ideology. A quarter of supporters of the government are made up of rural, religious people, who are authoritarians, and adherents of nationalChristian ideology. Now among the supporters of the government we can find the former left-wing party supporters, such as the pensioners, skilled workers and workers having only basic education, i.e., the so called "Kádár's small people", for whom the decrease of utility service prices, casual vouchers and the minimum wage increase are significant financial help. This less educated class is also receptive to the messages of government communication in refugee issues or anti-EU sentiment. This mass of government supporters is the decisive part of the so-called "central power field."

Most electors with 20\% votes, supporting opposition parties, are mainly from Budapest and metropolitan intellectuals who, due to their ideological attitude, are the advocates of liberal democracy and widespread political and liberty rights, reject social inequality, but support action against public corruption and emphasize the development of health and education. This social layer is not susceptible to nationalChristian ideology, devoted in its view to the values of the European Union and a broader integration with it, encourages a closer contact with the Western states and rejects the approach to Eastern dictatorships. This part of the voters has cover some of the right-wing intellectuals who voted for the ruling party earlier today.

The former far-right party, in which its new leader has purified the party from its extreme right members, currently defining itself as a conservative peoples' party. Among the opposition parties, this former far-right party has the highest support, with $20 \%$ of eligible electors. The two old left-wing parties are fragmented, full of inside fights, but still supported by the elder electors (10\%), who have nostalgy for the Kadar regime. Support of the new, Western-oriented party formed after 2010 is relatively low, $15 \%$. The support of the afore-mentioned old two left-wing political parties, which are the successor of the former communist party, was higher than that. There are small opposition political parties, too, with the low support of $1-2 \%$ of electors.

The supporters of government's policy consider state benefits more important to the values of liberal democracy. They accept the government's national values and conservative politics emphasizing the independence of the nation. Leftist and liberal opposition parties have a declining tendency, which reason, besides their fragmentation, is that leftist and liberal values are less and less popular. Support of electors of opposition parties is mostly related to the rejection of the autocratic Orbán regime, and expectation towards a new, modern and Western-type democratic state.

Almost a third of those entitled to elect do not vote, because their misery and poverty have led them to a hopeless situation that no one of political sides can provide any solution.

Any opponent of the ruling party could have a realistic chance at parliamentary elections to win only if a single political party replaced the current fragmented opposition parties, or if they would agree on a common candidate. There was little chance to it in a long term as the unification or the collaboration of opposition parties, until the parliamentary election of 2018, when the fragmented opposition parties suffered defeat, and the current governing party, the FIDESZ won 2/3 majority again of the Parliament's seats. The opposition parties could successfully make an opposition alliance during the last 3 years so that only one common candidate of their prime minister and their members of parliament can start in the parliamentary election of 2022. They are going to organize a primary election in the fall of 2021 to achieve this goal. There was a little chance earlier to it as the collaboration of opposition parties, given that they are from farright politics to leftist and liberal values, represent a wide range of ideologies, would lead to a massive loss of vote. Bearing in mind that these political differences were difficult to bring under common name. In addition, there is another breakthrough between the opposition parties: political parties formed after 2010 reject the former left-wing parties, given that they consider them responsible for the unsuccessful governance before 2010. Common element in the opposition parties' policy, however seemed to be stronger, 
i.e., the restoration of the liberal rule of law, the eradication of state corruption and the improvement of the education and health situation. The support of the current governing party of FIDESZ, on the other hand the electoral collaboration of the opposition parties is approximately the same, $50-50 \%$. The current government, however, has wide opportunities to manipulate the parliamentary election, and they use it, as well, in the practical reality.

The long-term governance of the ruling party from 2010 is assumed to ensure that it can acquire a relative majority by parliamentary elections in the future, too, which entitles them to form a government under the new electoral law. To maintain the relative majority, they had developed several strategies that seems to be successful so far.

It first transformed the media structure by placing public media under direct government control by appointing members of the public oversight body of the media loyal to the government, as well as removing a large part of commercial media from the market and then had bought it up with businesses close to the government. Due to the diversity of media, it is difficult to estimate that the government-based media created in this way, on the one hand, the government critical media, on the other hand, in which proportion reach the media consumers, but it is undoubtedly true that government media in this regard represent almost two thirds of the total.

The governing party from 2010 also announced a political party policy that is attractive to all social strata in some form. At the heart of its policy is the emphasis on national interests, in which it focuses on the independence of the nation and the right to sovereignty. In keeping with national economic interests, it promotes the creation of its own national capital class, economically strengthens the middle class, and provides various benefits for the poor. With this political party policy over the last 11 years, the support of about a third of the population eligible for voting could easily be maintained in the long run. The fact that the ruling party's economic and social policy is implemented not by means of the rule of law, but by the elimination of the principles of liberal democracy and by widespread state corruption is rejected only by the other third of the population. The 3rd third of the population does not participate in the elections.

The circle has been closed with this, as the governing party seems to be, in theory, detachable in democratic elections, but not in the practical reality. The ideology on the side of the government that the interest in stability is paramount, as the coalition governance of the divided opposition parties would lead to chaos is close to the truth, but the criticism from the opposition side that in the long run the elimination of the liberal democracy does not result efficient governance, and social justice is also correct. The division of the two political sides has been unprecedented since the beginning of the transition period, which completely excludes their cooperation.

\section{TRANSFORMATIONS OF PUBLIC LAW SYSTEM DUE TO THE PRINCIPLES OF ILLIBERAL DEMOCRACY}

\section{Questions of Centralization and Decentralization in the Public Administration}

The new constitution, created in 2012 left the basic institutions of the former state organisation, and expanded with new provisions that give a chance to the government's aspirations of monopolisation of political power. The new constitution hinders from many aspects the scope of the controlling bodies, such as the Constitutional Court, the State Audit Office, the ombudsman, also, the jurisdiction. As another success to suppress the control over the government, government loyalist members were appointed by the government, or elected by Parliament. This assured that government decisions were implemented in the state system without any obstacle.

The Constitutional Court's supervision developed until 2010, and the wide autonomy of municipal selfgovernment would have hindered the implementation of the new economic policy. It was because the Constitutional Court exercised widespread control over the legislature based on the concept of the interpretation of the "invisible constitution", and the autonomy of local governments was untouchable as a constitutional fundamental right. Other institutions, including the State Audit Office and the Ombudsman whose function is to control the executive branch of power are of less importance in this respect because 
they are one-man-guided, and so can be controlled more easily by the appointment of a politically loyal leader.

Justice, as the most independent branch of power, has been able to withstand the central government's aspirations due to the centuries-old tradition of juridical independence. In 2010 the government established the Court of Justice Office whose head is loyal to the governing party, has the right to appoint the judges, decides about tenders, and increases the salaries of the judges. This all allows the Office of Justice the opportunity to put political pressure on the jurisdiction. However, the Court of Justice Office, which had been established after 2010, pursued a successful attempt to eradicate the judicial independence by exercising the power of promotion and appointment over the judges. Compulsory retirement of judges in 2012 gave room to new loyalists for the government. The same political goal was promoted in 2018 by the proposed act on newly established administrative court with politically loyal judges, but the government finally withdrew it under the pressure of the European Union.

The limitation of the independence of the judiciary was most clearly achieved by the appointment of a politically loyal attorney general in 2010, because it is the right of the public prosecutor's office to investigate state corruption cases, also, to bring an accusation in them. In the absence of accusation, criminal proceedings cannot not be initiated before the courts, so the suspected corruption cases in business circles close to the government will not be brought to justice. Not accidently, the government did not join the newly established European Prosecution of the European Union, which - as opposed to its predecessor, the OLAF - has already had the right to apply criminal sanctions against individuals who commit corruption crimes related to the funds provided by the European Union for the EU member states, not only investigate and report to the domestic prosecutions. Politicians of opposition parties and investigative journalists have revealed day after day corruption cases of the government, but the people show very low interest to it. In Hungary, in 1990, a decentralised local government system with a strong autonomy was established. The municipal governments which otherwise exercised almost all the powers of local affairs, were too fragmented.

An administrative reform was announced in 2010 to make local and regional public administration more efficient by simplifying the organisation system, bringing the government closer to citizens, consolidating public procurement and digitalisation of public administration. The criticisms of the new administrative system suggest that the aim was rather to reduce the powers of the local government and to increase the influence of the central government at local level. To achieve this goal, the government focused on the centralisation in the field of development tasks. The central authorities have placed the EU funds under their provisions, which meant wide-ranging oversight, conciliation, approval, and review of the tenders of EU financial resources. In this way the government has incorporated the decision on the use of EU funds into the system of central government. This step, on the other hand, has increased the risk of corruption, but it has also created the conditions for EU funds to be placed in the business circles preferred by the government.

In the post-2010 local government elections, the ruling party overcame most local governments again and again, which ensured that the firms close to the governing parties would win most of the local government-wide tenders of the EU funds. After the local government elections in 2018, when many candidates of mayors and local government representatives had won the elections in the municipalities, the government pursued to "punish" these local governments having opposition majority, when withdrew their financial resources, even during the pandemic in 2020-2012, when local governments should have helped local business which went to bankruptcy, and individuals who lost their jobs too.

The allocation of the EU's development resources has never been free from political aspirations aimed at benefitting the "paraselene" of the respective government parties. It is true that the post-2010 government has far more opportunities to do so by making the role of the controlling bodies (State Audit Office and Public Prosecutor's Office) much restricted in this area, and in turn, it has built up a tendering framework based on political loyalty and personal dependency system.

From the time of the transition, the Hungarian public administration was known as being enormous, bureaucratic, and having low efficiency, however, several reforms were tried to resolve these problems. The law-making process since 2010 has also failed to meet the standards of the rule of law, because, for 
example, they implemented legal regulations made certain individuals or business groups beneficial or disadvantaged. The Constitutional Court, which had already been consisted of loyal members of the government at that time, did not annul these laws in politically significant cases. The most important drawback occurred since 2010 has been the growing state corruption on both central and local levels of public administration.

\section{The Fall of Economic Constitutionalism in the Illiberal Democracy}

By 2010, the Constitutional Court formed a significant counterweight to the public authority of the government and the parliament, so it constituted an important guarantee of constitutionality. The term "invisible constitution" means that the constitutional court may extend the content of the constitutional provisions by means of legal interpretation, thereby defining the basic foundations of the constitution and establishing a coherent system to hinder the government from modifying it through the legislature in accordance with current political interests.

According to the ideology of "majority democracy", the Constitutional Court exceeded its powers, because it took over a significant part of the parliamentary constitutional power. In 2012, therefore, the Government abolished the previous Constitutional Court decisions, and the new constitution greatly reduced the scope of the Constitutional Court's powers, particularly in economic matters. After 2010, the Constitutional Court did not play any significant role in the constitutional supervision of the government's economic activities. In the body of the Constitutional Court, every judge after 2010 was appointed by the governing party, so all of them are loyal to the government, rarely making decisions against the economic policy of the government.

Underestimating constitutionalism on such a large scale may undermine the requirements of economic efficiency - public policy approaches, stability, predictability, accountability, and quality legislation which will confuse the market participants who will evaluate it as inadequate economic governance decisions. When the government drastically restricted the constitutional review, it regarded these considerations as secondary, because it was much more important for them that constitutional supervision over government economic policy decisions no longer should constitute a limitation in the future.

The government having two-third majority in the parliament in 2010, appointed a person who is politically loyal to it as the head of the State Audit Office. After 2010, the State Audit Office did not investigate the use of public funds, nor disclose shortcomings. All of this exacerbates the government influence. The government denies that the economic policy of strengthening its "paraselene" by granting their supporters state property, low interest credits of state-owned banks, state subsidies, or EU financial resources would be state corruption, because this kind of economic policy has been regulated by law. These acts that should be the subject of constitutional problems, and the lawfulness of public procurements, however, are never queried, because of the lack of impartiality in the operation of controlling authorities, such as the Constitutional Court.

Since 2010 the government has declared that it as an essential feature of its economic policy, saying that it has the right to establish a wealthy business class and a discrete middle-class, both are loyal to it, and compensate the former overwhelming economic and media power of the successors of the former communist party.

Since 2010, the government has openly announced that the goal of use of European Union funds is to create a so-called "national capitalist class", and therefore the purpose of the public interest is to provide immovable property to people close to the government and this is not a state corruption. Most public tenders for funding are won by businesses close to the government, in a likely manipulated procedure. However, because of the lack of substantive supervision by the controlling authorities over the use of public funds, which is in this way under close government control, the revelation of corruption cases is limited to interpellation of the opposition, and media investigative articles. Even those cases are not subject to prosecution, in which state corruption is evident. Prosecution investigations, however, are rarely initiated or seldom ended with accusation. 


\section{THE ESTABLISHMENT OF MARKET-ORIENTED ECONOMY INSTITUTIONS DURING THE TRANSITION}

\section{Privatisation as a Tool of Economic Governance}

At the beginning of the transition period, market competition, business companies, pricing, employment and social security were subject to new legal regulations. These laws regulated the new market economy institutions that broke with the bureaucratic economic governance system of the Communist state and its paternalistic social policy. The new economic governance applied the principles of market competition, freedom of enterprise and equality of ownership.

The first step towards the market economy was the privatisation of state-owned enterprises. The biggest challenge was to make private ownership dominant in the business sector, because a huge amount of stateowned enterprises' property should be sold. Political struggles have always accompanied the privatisation processes since the beginning of the transition, because the political parties have seen the possibility of strengthening their economic positions through their respective interest groups in privatisation. Therefore, the assessment of privatisation is difficult from the point of view of economic efficiency because it has in most cases served as a political endeavour and not for the public interest. The literature describes the first form of privatisation in 1988-89 as "spontaneous privatisation" because the decision on privatisation remained in the hands of state-owned enterprises, and the revenue derived from the privatisation, remained with the transformed business firms. (Sárközi T. 2009. 34.) The earlier economic reforms of the 1970-s and 1980-s granting wide autonomy rights to the state-owned enterprises and gave them the opportunity to make certain economic decisions. According to many opinions, national wealth was "squandered" because in most of the national property was obtained by the old Communist party elite at low prices. Although no survey on this has stated this yet, it is widely believed that the economic power of the successors of the former Communist party is based upon this kind of privatisation.

Since 1990, after the first democratic government was formed, spontaneous privatisation worked against the interests of the new democratic government, which wanted to bring its own party members into the most important corporate positions and needed revenues from privatisation for state debt repayment as well. This stage of privatisation is termed "political privatisation" because the State Privatisation Agency, under strict government control, decided on privatisation using its discretionary legal authority based on tenders whose criteria, aspects and procedures were not regulated by law. This privatisation practice has been criticised many times, and most of all, because of the lack of legality and democracy. Privatisation, therefore, slowed down, became bureaucratised and evolved into a hotbed of corruption. (Ágh A. 1991. 5860.)

The Privatisation Act of 1995 passed by the second democratic government, the so called "privatisation of privatisation", made the privatisation more lawful and democratic, by regulating the procedural guarantees of tendering and allowing other social groups, than the political elite and the foreign business firms, to participate in the privatisation. For privatisation, this law established economic priorities, additionally obliging the government and parliament to jointly define privatisation strategy. However, by this time, the former government had already privatised most state-owned enterprises in the business sector.

In the subsequent period, legal regulations allowed the privatisation of more and more property formerly belonging to the state, exclusively through government decision-making, which meant that by the end of the 2000s only the public transportation utilities, the water supply and the mines owned by the treasury, remained in exclusive state ownership. There are no reliable data on the extent of corruption in the privatisation processes, but according to a report made by the State Audit Office, approximately a quarter of state assets disappeared during privatisation.

In accordance with most of the opinion, the privatisation in Hungary was rushed, because the share of state ownership was reduced to unduly low levels, and therefore strategic assets of the national economy came under ownership by foreign companies. This tendency made way for globalisation and a chance for the multinational enterprises to infiltrate into Hungarian economy, which had some negative impacts too. Because of their economic weight, multinational enterprises have been able to influence the government's 
economic policy decisions to provide a favourable economic environment for them: low public burdens, state subsidies and cheap labour.

\section{Shaping Economic Policy by the Left-Wing, the Liberal and the Right-Wing Parties}

At the beginning of the transition period, the Hungarian economy lost its earlier potential for dynamic development, since after the disappearance of the markets of the former Communist countries; it became apparent that it was no longer competitive in the world economy. (Lentner Cs. 2010. 11.)

This was still borne out by the economic anomalies caused by the transition to the market economy already mentioned. Privatisation revenues did not cover the public debt and could not compensate for significant losses in the state budget. The budget deficit was also heightened by the fact that the distribution of the budget was disproportionate because massive unemployment emerged affected by the disappearance of state-owned companies, and this resulted in a downsizing class that was not competitive on the labour market. However, this sector still expected state care, which led to widespread welfare expenditure. During the Communist period, there were no traditions of taxation because of which the emerging grey economy was based on illegal labour and tax evasion. The revenues of the budget had therefore significantly decreased. Because of these reasons, the government deficit and government debt were so high that state bankruptcy threatened.

The fiscal balance in the mid-1990s was restored by the economic policy of the Socialist-Liberal Government, known as the "Bokros package", which sought to reduce consumption by reducing incomes, mainly by cutting social spending. The irrefutable differences of opinion between the two political sides were beginning to emerge.

According to right-wing politics, the governance of the left-wing party meant a Communist legacy, because it saw any conceivable economic reform only in restricting the population, and demanded from the middle class a sacrifice, which later proved unnecessary. It did not focus on investment, development, and employment, either, but supported the poor in a great extent in the form of social assistance. Its economic policy was considered neoliberal, which did not fit the traditions of the Hungarian economy. The left-wing welfare policy remained a distributor, merely with the political goal of buying votes.

Another reason for the instability of the economy was the low efficiency of the state because the public administration was bureaucratic, wasteful, and corrupt, and its size was overwhelming.

In the late 1990s, right-wing economic policy supported the investments of domestic small and medium-sized enterprises, housing construction, and implemented state investments with which they created jobs and increased the living standard. This government raised the minimum wage, created a new employment policy for the dislocated stratum of the labour market, and built up the family support system. This economic policy concept used the Keynes demand-driven fiscal policy instruments against the austerity measures of the left.

By the end of the 2000s - not least because of the impact of the global financial crisis - an economic crisis emerged in Hungary, which the left-wing liberal government sought to address with additional restrictions on the population and an increased tax burden on businesses, as a condition of credit provided by the National Monetary Fund. A large majority of the population by then did not support the government's economic policy.

The so-called "unorthodox" economic policy introduced in 2010, defines itself as being against neoliberal economic policy, and it entitles the state to have an active role in managing economic processes. Its economic policy was built on anti-globalisation and the emphasis on national economic interests and on increasing the welfare of the population. (Matolcsy Gy. 2008. 107-115.)

As a tool, it increased the share of state ownership and the number of state monopolies, introduced robust money market regulation, multinational corporations with special taxes, supported business enterprises loyal to the government, increased state investment, and employment by public works, established favourable tax conditions for the middle class and reduced the social assistance.

Increase of state ownership was achieved by reorganising the market in such a way that state-owned enterprises and business firms close to the governing political party benefited from certain sorts of advantages conceded by the government. Thus, these new economic stakeholders could expel the former 
market players. Due to the special taxes, a large part of multinationals in the banking sector, the media market, the energy sector, and the telecoms market have suffered significant losses, which forced them to give up their operation in the country. One exception can be mentioned: in the aware of determining influence of Germany in the European Union, German business enterprises received sufficient financial state supports from the Hungarian government to reach in this way a more lenient treatment for itself from the side of the European Union which would have been strong intent to hinder the growing development of illiberal democracy in Hungary.

As another way, the state has made acquisitions, expanded the state monopolies, or withdrew local public tasks and services from local governments, and placed them within the scope of state power. This facilitated the redistribution of the markets, with more intense economic intervention. It provided for the government's economic "paraselene" very significant financial assets to achieve equality with the benefits of the left-wing entities in this area. In the media market, the state advertising orders fundamentally determine the profitability of the media service providers, which is a good tool for leveraging governmentfocused media and taking out the government critical media from the market. In the banking sector, the state-owned banks offer preferential loans to start up-to-run businesses close to the government, and to purchase of certain economic sectors of businesses close to the government.

The "unorthodox economic policy" could stabilise the economy, keep the budget deficit below the expected 3\%, trigger economic growth (though not as expected), economically strengthen its own voting power, and promote economic positions of strength for the government through its own " paraselene ". Additionally, in fact, it built its own media empire, as well.

Despite the anomalies, the "unorthodox economic policy" is supported by a wide range of people, and its success is basically due to its rhetoric breaking with the previous economic policy but emphasising welfare principles and the interests of a national economy as opposed to neoliberal principles. Strong, centralised public administration seems to be more closely aligned with Hungarian traditions, keeping economic processes under control by having a well formulated and strong economic purpose, which provide care for its favoured and loyal middle-class citizens and wealth for its "paraselene". It is argued that the neoliberal state based on the "laissez faire" principle, which trusts in the omnipotence of the market and encourages citizens to self-help, is a foreign body in Hungarian public administration. The left-wing political side represented a neo-conservative economic policy that was increasingly rejected by the population.

In the practical reality the "unorthodox" neoliberal economic policy of the government eliminated a most traditional constitutional right, the economic equality by supporting financially the favoured and loyal individuals and business firms and abandoned the rest of them in poverty. The argument of the government to it is that people are not loyal to the government, or against the national-Christian ideology of the government should be considered as left-wings or liberals who do not belong to the Hungarian nation.

Paradoxically, this new economic policy with its ideology was not realised by the old-new elite that had grown up in the era of Communism, but by the new right-wing political group emerging in democracy since 1990 s.

The "unorthodox economic policy" using unusual methods in advanced market economies are not easy to judge from the point of view of economic efficiency. The state was able to increase its controlling role in economic processes, to facilitate state interventions, and to achieve its social and economic goals fast and easily, but at times it could not so, but instead, it resulted another one than it was intended.

The "unorthodox economic policy" has also shown serious shortcomings over the past eleven years, as well. To implement the central political will quickly and easily, the government, commanding a two-thirds majority of parliamentary seats, has largely repressed the aspects of economic constitutionalism, along with, at many points, the institution of the rule of law, the market competition, and the economic equality. From many perspectives, it was not able to achieve more efficient governance, either. Poverty is growing, the employment growth rate is based solely on the introduction of underpaid public work, which is not a realistic alternative for entering the labour market, and the levels of health and education have declined further. This economic policy is a contradiction of competitive economy, as well, in the long run. 


\section{Public Utility Prices as a Tool of the Politics}

In the Communist economic governance system, public utilities (energy, telecommunications, transport, water, and sewage) were provided by state-owned public utility enterprises, which, despite the reforms aimed at economic autonomy, remained under close state administrative control. The reason for this was that the Communist state regarded public utilities as goods forming part of basic needs, whose price was set at a much lower level than the market price by price regulation. The efficiency and profitability of utility companies did not become a priority, but the focus was more on the general availability of services.

During the transition period, the privatisation of infrastructure public utilities in Hungary took place in the second half of the 1990s. The state declared infrastructure public services to be a state monopoly, the operation of which was only possible for private companies in the form of concessions. Concessions lost their significance in the 2000s when the government liberalised the infrastructural public sector in line with $E U$ directives, enabling any enterprise to enter the market, thereby creating a competitive market.

In Hungary, the price of infrastructure public services has become a field of political struggle since the 1990s. The welfare gained in the Kádár era was lost by a large part of the population at the beginning of the transition period, who still insisted on state care, one of which was the low price of public utility and transport services. In the early $1990 \mathrm{~s}$, therefore, the government had a major political interest in keeping the price of infrastructure public services at a low level, even at the cost of state-owned public utility companies making a loss, rather than their being privatised.

The issue of efficiency arose when public infrastructure services were privatised in the mid-1990s. At that time, the profit-oriented companies providing higher quality, but a more expensive service, faced the low-cost and low-quality public service companies. It was complicated by the fact that the price of these utility services was determined by the administrative bodies at a legislative level, in conformity with a less regulated aspect, upon which the public service company had no influence.

It was a continuing debate that the government-established energy prices were indeed aligned with world market prices, as governments have regularly argued, or, according to opposition critics, the government's price control practices provided extra profits to foreign investors in the energy sector. This question proved to be unanswerable because it was not based on objective calculations, merely upon political views.

Price regulation in the energy sector, which had been the central issue of the election campaigns from the beginning, took a new turn in 2010. The election promise made by the government set up in 2010 was the so-called "decrease of utility service prices", consistently implemented not only in energy services, but also in transport, water, and canal services.

The ongoing liberalisation process was stopped. By the end of the 2000s state monopolies disappeared in the public service sector, because of liberalisation policies, and the price regulation became the exception. From 2010, the government tried to buy the service companies in the infrastructure public service sector, which was easy, because companies in foreign ownership suffered serious losses, due to the drastic decreases foreseen in the price regulations of public services. The government aimed to squeeze out the companies that had already been in the market, as well as by creating new state-owned public service companies with more competitive conditions, such as grants of state subsidies, or EU development resources. In other cases, the government declared the public service as a state or municipal monopoly, or, invited new tenders in which newly established state-owned applicants became winners, and the old ones were pushed out.

The aim of this economic policy since 2010 was to increase the share of state ownership and the number of state monopolies in the infrastructure public sector, which served as a tool to reduce the ability and bargaining power of multinational companies in the government price determination. As a result, more and more infrastructure public services - energy services, all sectors of transport, parking, highway tolls, universal communications, water and sewerage services, and waste collection - have again been subject to price regulation for the purpose of reducing the prices. Determination of the prices, even in the case of local public services, is a discretionary power of the central government.

Within a short time, this has brought spectacular political gains, but in the longer term, the government will have to compensate for the losses of state-owned public utility companies, also, provide additional 
resources for their development in order to maintain the quality of public services together with the somewhat lower prices.

\section{Economic Policy Supporting the National Capitalist Class}

From 2010, the right-wing government broke with this practice and renewed the so-called "Széchenyi Plan," which was first established at the end of the 1990s, supporting domestic small and medium-sized enterprises in Hungary arguing that the ability of such enterprises to create jobs is much greater and the taxes paid by them are more significant than those paid by multinational corporations.

The structure of agriculture in Hungary has been unfavourable since the 1990s. After the disappearance of the state-owned farms, smallholdings obtained the lands as compensation for the nationalisation of their former lands by the Communist Party, which became dominant in agriculture. This structure of agriculture had low competitiveness due to the lack of capital. The situation was further aggravated by the fact that the market for agricultural purchases was monopolistic, and the small farmers' ability to enforce their interests was low. Consequently, a process of concentration started, in which small family estates became either uncompetitive or were ruined.

In 2010, the Government adopted a new rural development strategy, worked out the so-called "popular party agricultural policy" in which it applied tendering for the lease of state-owned land, and thus aimed to provide land for the farmers. However, the local "paraselene" won in the reality most of the tenders and established large agricultural estates this way. The EU financial supports were transferred in most cases to these new landowners, too, by way of public procurement. Land privatization thus did not achieve the economic policy objective of becoming a wider layer of family farms in livelihoods in agriculture. However, it reduced the proportion of land leased by foreign owners to the benefit of Hungarian land tenants, which is closely related to the government's foreign-owned economic policy. The government also restructured the agricultural market in to provide greater protection for farmers and to allow for the development of agricultural holdings. It provided financial aid to farmers for modernization and purchasing of farming machines too.

The scope of state monopolies has increased not only in the public service sector but also in the business sector since 2010, which is an unusual phenomenon in the market economy-based Western management systems. The purpose of this is to obtain new markets for the enterprises close to the government party. The government accomplished this goal by declaring several economic activities as a state monopoly, and then by setting up public companies in these markets and donating them favourable market positions. New tenders were issued after having declared these activities state monopolies, and in a non-fair competition, the government preferred their own holdings by granting them the right of the operation of these economic activities.

\section{Reforms of the Welfare System}

In Hungary, during 40 years of Communism, the state provided welfare for individuals and raised their standard of living, especially in the late Kádár era. During the transition period, when the economic conditions of the population deteriorated because of the economic downturn and economic restructuring, governments had a major political loss in the drastic reduction of welfare services. The difficulty was that, since there was no tradition of tax liability in the Communist era, a large part of the population who obtained income from the grey economy or a company that could avoid paying public debts, did not pay any social security contributions. It would have served, however, as the financial basis for most welfare services.

The public felt that the public debts to which they were required to pay were too high, and that the state was using public money in a wasteful way, and because of the corruption of the political elite public money was becoming private assets. As a result, the level of public services was declining. Only long afterwards, by the end of the $2000 \mathrm{~s}$, did the techniques used to filter out "free riders" from the beneficiaries of welfare services develop. From the end of the 1990s, the Tax Administration Office became an ever stronger and more powerful public administration organisation, and in addition to administrative fines, it also received the power to law enforcement. 
Since the so-called "Bokros package" period from 1995, social security services - the level of pension, health services, unemployment benefits and certain welfare benefits - had continually decreased. Left and liberal governments have been accused of supporting only lumpen elements that do not want to work with the provision of large-scale social assistance. It has resulted in generations of this social group the tradition that they are not earning income but receiving social aid. However, there are those who say that the status of this social layer is basically determined by the low potential on the labour market, and the lack of job opportunities in some regions of the country. The middle class had been less and less supportive of the extensive social support system for the poor, then argued that it does not even encourage work because there is virtually no difference between the salary of the lower middle class, and the income earned by social assistance.

The level and availability of welfare benefits declared since 2010, the so-called concept of a "workbased society", meant that, as a rule, everyone should work, which signified the government wanted to provide public work, but it did not mean real job opportunities, but something rather in the nature of forced labour. It is so much the more, because the wage for public work is the half or less of the minimum wage or it is not always available. Those who do not have public work, but would like to work, get $\$ 60$ as a state aid in a month, which is evidently not enough to survive. The creation of public work opportunities is the responsibility of local governments, which puts public employees into a dependency position, and can be used for political purposes, such as buying votes.

From 2010, the government has provided grants to the middle class, largely to support only those who have access to work at a certain level of income, such as family tax relief for children, state loan for buying homes, and childcare allowances. In parallel, it introduced the flat tax system, which also increased the income of higher income groups. Family income support can be used primarily by the higher income earners, too.

At the same time, from 2010, the government has drastically reduced social assistance for the poor, which, moreover, only goes without the availability of public work in the given settlement. The government set up in 2010 a radical cut of social aid affirming that anybody had the opportunity to undertake public work and can live on this, too, which later did not seem to be true. The children allowance, which is quarter part of the family tax allowance, is subject to having high income, which the poor do not have.

This social policy, with preferring those who have work and have higher income, openly supports the willingness of the middle class to have children and makes the poorer strata counter appealing. With this social policy, the government gained considerable support from the middle class, at the same time it has resulted that the numbers of poor people have dramatically increased during the last eleven years.

\section{SUMMARY}

The fall of liberal democracy in Hungary in 2010 is due to several reasons. Liberal democracy has no traditions in the country's modern history. The Horthy system in the first part of the 20th century was a multi-party parliamentary system with autocratic features, emphasizing authoritarianism and conservative national traditions.

The half-century existence of the communist system also hindered the development of democratic traditions in Hungary. At that time, reforms of the Communist economic governance model since 1868 was a step forward, but it established unfavourable traditions too, which later became disadvantageous for the modernisation processes.

The paternalistic social policy of the Kádár system put an end to self-care of the population, which led to a public attitude to wait from the state to take care of the population. There was also a lack of demand for democracy because everyday living for the population was more important than participating in political decision-making processes. Furthermore, the time of transition in Hungary was peaceful, which led to continuity in the society, as opposed to the other post-communist country in the region, where dictatorships were overthrown by revolution. With these traditions emerging in the Kádár regime, the institutions of liberal democracy could not be built up in the long run. Instead, the need for a strong, centralised state grew and later gained broad support from the population. 
It has been also clear that the former Communist elite was not entirely deprived of its political and economic power. As a result, they succeeded in successfully transforming their political power into an economic power from the second half of the 1980s, which, from the time of the transition, made it possible for the former communist party's successor, the recent socialist party, to build its own "paraselene" and media overweight. All of this, and the wide support of the so-called "Kádár's small people" with which they obtained their votes, gave them the opportunity to win most of the elections since the mid-1990s.

However, in the socialist party, in the coalition government with the newly established liberal party, beyond the paternalistic politics for the poor, it pursued a neoliberal economic policy that was based on the emphasis of market mechanisms, the state's non-interference in economic processes, and self-care. In the Hungarian society, however, there were no traditions of liberalism, much rather a limited recognition of political and freedom rights, and it is not considered as primary goal to assure equal opportunities. The economy of the country has been exposed by the socialist and liberal governments to the effects of globalization by over-privatization, and they have not sufficiently supported the strengthening of the domestic capitalist class and middle class, that are committed to national values.

The right-wing party introduced illiberal democracy from 2010 believed that it had to compensate for its disadvantaged situation, and therefore over-asserted its political power by means of public law, which, through its social and economic policies, was the first to receive support from the middle class and then from the "Kádár's small people". The success of this policy has been greatly contributed to the fact that neoliberalism has also been in crisis because of the global economic crisis in 2008, and a growing expectation of a strong state that can solve public interest problems quickly and efficiently.

However, this raises a question: does the end justify the means in the sense that is it worth sacrificing the values of liberal democracy for the hoped greater efficiency?

The extent of state corruption and social inequality has continued to increase, employment indicators have only been improved by the ratio of public work and the more hundred thousand emigrants, also, the quality of education and health has not improved. The positioning the "paraselene" to favourable economic position and distributing EU funds in this sense has eliminated market competition and will further undermine the competitiveness of the economy in the longer term. The society has been divided into three parts: the "paraselene", which is a very slim class has become spectacularly rich, the income of the middle class has improved, although it shows a tendency to deteriorate in the EU comparison (which has led to mass migration of the employees, and later to a shortage of labour), and the position of the poor living in a relative, or deep-seated poverty has not changed.

The "majority democracy" expressed by the ruling party, means that in the electoral system created in 2010 , de facto, with a vote of $25-30 \%$ of the electorate, the government can obtain an absolute majority in Parliament. In accordance with the statistics, most of this $25-30 \%$ of the electorate come from the less educated sectors of the population of the rural areas, who are particularly receptive to the populist ideology of the governmental media, also, from the beneficiaries of the Orbán regime. The number of the latter ones cannot even be estimated, due to the wide state corruption which allocates sufficient incomes in many ways to the followers of the government. A further $30 \%$ of the electorate devoted to the values of the liberal democracy but could not articulate their political interests in the fragile and weak opposition parties, at the same time in an autocratic political and government system. The rest of the electorate are unwilling to vote due to their miserable and desperate situation, or if do so, their votes are bought. Only a slim class, the so called "new bourgeois" has become a real beneficiary of the illiberal democracy in Hungary.

\section{ENDNOTES}

1. Romanian name is Băile Tuşnad

2. Fukuyama, Francis (1989). "The End of History?". The National Interest (16): pp 3-5. Published by Published By: Center for the National Interest, ISSN 0884-9382.

3. Downloaded from Global democracy has another bad year | The Economist on 30/07/2021

4. Downloaded from Democracy Index 2020 - Economist Intelligence Unit (eiu.com) on 30/07/2021 
5. Interview in Hermann Goering's jail cell, April 18, 1946. "Nuremberg Diary". Book by Gustave Gilbert, 1947.

6. Faith Agostinone-Wilson: Enough Already! A Socialist Feminist Response to the Re-emergence of RightWing Populism and Fascism in Media, Oklahoma State University USA, Critical Media Literacies Series Volume 4, 2020, Chapter 2, p 32. ISBN 978-90-04-42452-4

7. Category Archives: Tusványos Summer University https://theorangefiles.hu/category/tusvanyos-summeruniversity/

8. This phrase was used first by the prime minister Viktor Orbán in his well-known speech of Kötcse, in 2007., when he summarized his political program. The „central power field” means in this context the necessary leading role of the recent governing party in the political system.

\section{REFERENCES}

Ágh, A. (1991). A privatizáció politikai szemszögből. Társadalmi Szemle, 4, 16-18.

Agostinone-Wilson, F. (2020). Enough Already! A Socialist Feminist Response to the Re-emergence of Right-Wing Populism and Fascism in Media. Critical Media Literacies Series, 4(Chapter 2), p.32. Oklahoma State University USA. ISBN 978-90-04-42452-4

Fukuyama, F. (1989). The End of History? The National Interest, (16), 3-5. Center for the National Interest. ISSN 0884-9382

Istvan, C., \& László, L. (1985). Vállalkozás, állam, társadalom (pp. 195-243). Közgazdasági és Jogi Könyvkiadó, Budapest.

Kornai, J. (1991). A privatizáció elvei Kelet-Európában. Közgazdasági Szemle, XXXVIII(11), 021-1040.

Lentner, C. (2010). Valóban magasabb szintü gazdasági modell a magyar piacgazdaság, mint a piaci elemekkel átitatott tervgazdasági rendszer? Heller Farkas Füzetek, 8(1-2).

Lőrincz, L. (1981). A közigazgatás kapcsolata a gazdasággal és a politikával. Közgazdasági és Jogi Könyvkiadó, pp. 187-226. Budapest.

Matolcsy, G. (2008). Éllovasból sereghajtó - Elveszett évek krónikája. Éghajlat Könyvkiadó, pp 211213. Budapest.

Romsics I. (1997). A Horthy-rendszer jellegéről. Elitizmus, tekintélyelv, konzervativizmus. Rubicon Online. Retrieved April 23, 2021, from http://www.rubicon.hu/magyar/oldalak/a_horthy_rendszer_jellegerol_elitizmus_tekintelyelv_konzervativizmus

Sárközy, T. (2009). A korai privatizációtól a késői vagyontörvényig - Az állami tulajdon jogának fejlödése HVG ORAC Lap-és Könyvkiadó Kft (p.34). Budapest.

Sárközy, T. (2009). A korai privatizációtól a késői vagyontörvényig - Az állami tulajdon jogának fejlödése HVG ORAC Lap- és Könyvkiadó Kft (p.39). Budapest.

Zakaria, F. (1997). The Rise of Illiberal Democracy. The Next Wave. Council of Foreign Relations, Inc., USA. Retrieved from https://www.foreignaffairs.com/articles/1997-11-01/rise-illiberaldemocracy 